\title{
Rhodoblastus sphagnicola sp. nov., a novel acidophilic purple non-sulfur bacterium from Sphagnum peat bog
}

\author{
Irina S. Kulichevskaya, ${ }^{1}$ Vladimir S. Guzev, ${ }^{2}$ Vladimir M. Gorlenko, ${ }^{1}$ \\ Werner Liesack ${ }^{3}$ and Svetlana N. Dedysh ${ }^{1}$ \\ ${ }^{1}$ S. N. Winogradsky Institute of Microbiology, Russian Academy of Sciences, Prospect 60-letya \\ Octyabrya 7/2, Moscow 117312, Russia \\ ${ }^{2}$ M. V. Lomonosov Moscow State University, Faculty of Soil Science, GSP-2, Leninskie Gory, \\ Moscow 119992, Russia \\ ${ }^{3}$ Max Planck Institute for Terrestrial Microbiology, D-35043 Marburg, Germany
}

Correspondence

Svetlana N. Dedysh

dedysh@mail.ru
The purple non-sulfur bacteria (PNSB) are a highly diverse and metabolically flexible group of anoxygenic phototrophic bacteria that grow phototrophically under anoxic conditions in the light or chemotrophically under microoxic to oxic conditions in the dark (Imhoff, 2001a). These phototrophic micro-organisms belong to the Alphaproteobacteria and Betaproteobacteria but do not form monophyletic groups within these phyla (Woese et al., 1984;

\section{Abbreviation: PNSB, purple non-sulfur bacteria.}

The GenBank/EMBL/DDBJ accession number for the 16S rRNA gene sequence of strain $\mathrm{RS}^{\top}$ is $\mathrm{AM} 040096$.

The absorption spectrum of a cell homogenate of phototrophically grown strain $\mathrm{RS}^{\top}$ and a graph showing the influence of $\mathrm{pH}$ on growth of strain $\mathrm{RS}^{\top}$ are available as supplementary material in IJSEM Online.
Stackebrandt et al., 1988; Kawasaki et al., 1993; Imhoff \& Trüper, 1992; Imhoff, 2001a). Instead, many representatives of the PNSB are closely related to non-phototrophic, strictly chemotrophic bacteria.

PNSB are widely distributed in various aquatic ecosystems as well as in sediments, moist soils, natural wetlands and paddy fields (Pratt \& Gorham, 1970; Burke et al., 1974; Imhoff, 2001a). Stagnant water bodies with significant amounts of soluble organic matter and low oxygen tension are the preferred habitats for these bacteria. Sphagnum peat bogs exemplify this kind of environment. However, in contrast to other freshwater habitats, peat bogs are rarely reported as sources of PNSB. The low $\mathrm{pH}(3 \cdot 5-5 \cdot 5)$ and extremely low mineral salt contents $\left(5-50 \mathrm{mg} \mathrm{l}^{-1}\right.$ in peat water) are possible reasons for this. So far, taxonomically 
characterized PNSB from this acidic habitat are represented by only one strain, strain 3251, which was isolated from a Sphagnum peat bog near Kolshorn/Hannover (Germany) and subsequently described as a strain of Rhodopseudomonas acidophila (Pfennig, 1969). Later, this taxon was reclassified as Rhodoblastus acidophilus (Imhoff, 2001b). Here, we describe another example of PNSB isolation from acidic Sphagnum peat.

In the course of a study on cellulose degradation in Sphagnum peat, we detected intensive development of some phototrophic purple bacteria in anaerobic cellulolytic enrichments incubated under light. Several strains of PNSB that were morphologically and phenotypically similar to Rbl. acidophilus were isolated from these enrichments. These strains had the same morphology and physiological traits and possessed identical 16S rRNA gene sequences: thus, only one of these isolates was studied in detail. These phenotypic and genotypic studies revealed a number of features that distinguished $\mathrm{Rbl}$. acidophilus from the newly isolated strain. Thus, we conclude that it represents a novel species of the genus Rhodoblastus.

The sample used in our study was collected from $5-10 \mathrm{~cm}$ below the surface of an acidic peat ( $\mathrm{pH} \mathrm{3 \cdot 5-4 \cdot 2)}$ underlying the Andromeda-Eriophorum-Sphagnum plant community in the raised centre of the Sosvyatskoe ombrotrophic bog located in Tver Region, West Dvinskiy district, at the field station of the Institute of Forestry, Russian Academy of Sciences $\left(56^{\circ} 10^{\prime} \mathrm{N} 32^{\circ} 12^{\prime} \mathrm{E}\right)$.

Anaerobic cellulolytic communities were enriched using screw-cap $120 \mathrm{ml}$ serum bottles containing $30 \mathrm{ml}$ liquid mineral medium of the following composition [ $\mathrm{g}$ ( 1 distilled water $\left.)^{-1}\right]: \mathrm{KH}_{2} \mathrm{PO}_{4}, 0 \cdot 04 ; \mathrm{NH}_{4} \mathrm{Cl}, 0 \cdot 1 ; \mathrm{MgCl}_{2} .6 \mathrm{H}_{2} \mathrm{O}, 0 \cdot 01$; $\mathrm{CaCl}_{2} \cdot 2 \mathrm{H}_{2} \mathrm{O}, 0 \cdot 05$, with the addition of $0 \cdot 1 \%(\mathrm{w} / \mathrm{v})$ cellulose, $0.5 \%(\mathrm{v} / \mathrm{v})$ trace element stock solution (Pfennig \& Lippert, 1966) and $0 \cdot 1 \%(\mathrm{v} / \mathrm{v})$ vitamin stock solution (Wolin et al., 1963). The initial $\mathrm{pH}$ of the medium was $5 \cdot 5$. The inoculation was done with $100 \mathrm{mg}$ peat, and the bottles were closed with silicone-rubber septa, flushed with sterile $\mathrm{N}_{2}$ and incubated at $25^{\circ} \mathrm{C}$ in the light $(2000 \mathrm{~lx})$. As soon as visual development of purple phototrophic bacteria in these enrichments occurred, an aliquot was taken for pure-culture isolation. This was achieved by means of repeated deepagar $(0.8 \%)$ dilution series on succinate mineral medium (Pfennig, 1969). An isolate obtained was designated strain $\mathrm{RS}^{\mathrm{T}}$. Culture purity was ensured by examination under phase-contrast microscopy and by the absence of colourless colonies in a column of agar succinate mineral medium. Physiological tests were performed in liquid medium no. 27 recommended by the Deutsche Sammlung von Mikroorganismen und Zellkulturen (DSMZ, Braunschweig, Germany) under anoxic conditions in the light (2000 lx). Rbl. acidophilus ATCC $25092^{\mathrm{T}}$ was used as a reference strain. Growth of strain $\mathrm{RS}^{\mathrm{T}}$ was monitored by nephelometry at $600 \mathrm{~nm}$ for $7-10$ days under a variety of conditions, including temperatures of $10-37^{\circ} \mathrm{C}, \mathrm{pH} 4 \cdot 0-7 \cdot 5$ and $\mathrm{NaCl}$ concentrations of $0 \cdot 01-3 \cdot 0 \%(\mathrm{w} / \mathrm{v})$. Variations in the $\mathrm{pH}$ were achieved by mixing $0 \cdot 1 \mathrm{M}$ solutions of $\mathrm{HCl}$ and $\mathrm{KOH}$. The range of potential growth substrates for strain $\mathrm{RS}^{\mathrm{T}}$ was examined using $0 \cdot 02-0 \cdot 05 \%(\mathrm{w} / \mathrm{v})$ concentrations of the following carbon sources: acetate, arginine, benzoate, butyrate, caproate, citrate, ethanol, formate, fructose, glucose, glutamate, glycerol, lactate, malate, malonate, mannitol, propionate, pyruvate, succinate, tartrate and valerate. The capacity to utilize methanol was determined at a range of concentrations from 0.01 to $3 \%(\mathrm{v} / \mathrm{v})$. Tests for photolithotrophic growth with molecular hydrogen and carbon dioxide were performed in screw-capped $120 \mathrm{ml}$ serum bottles containing $30 \mathrm{ml}$ mineral medium no. 27 with a gas phase of $\mathrm{H}_{2} / \mathrm{CO}_{2}(80: 20, \mathrm{v} / \mathrm{v})$. Growth was examined after 7-10 days incubation under light by comparison with a negative control. Tests for the ability to grow in the dark under aerobic conditions were performed using both liquid and agar succinate mineral medium (Pfennig, 1969). The capacity to develop in nitrogen-free media was tested using liquid mineral medium no. 27 without yeast extract or $\mathrm{NH}_{4} \mathrm{Cl}$.

For the preparation of ultrathin sections, cells of exponentially growing cultures were collected by centrifugation and pre-fixed with $1.5 \%(\mathrm{w} / \mathrm{v})$ glutaraldehyde in $0.05 \mathrm{M}$ cacodylate buffer $\left(\mathrm{pH} \mathrm{6.5)}\right.$ ) for $1 \mathrm{~h}$ at $4{ }^{\circ} \mathrm{C}$ and then fixed in $1 \%(\mathrm{w} / \mathrm{v}) \mathrm{OsO}_{4}$ in the same buffer for $4 \mathrm{~h}$ at $20^{\circ} \mathrm{C}$. After dehydration in an ethanol series, the samples were embedded in a Spurr epoxy resin. Thin sections were cut on an LKB-4800 microtome and then stained with $3 \%(\mathrm{w} / \mathrm{v})$ uranyl acetate in $70 \%(\mathrm{v} / \mathrm{v})$ ethanol. The specimen samples were examined with a JEM-100C transmission electron microscope (JEOL).

The absorption spectra of living cells were recorded with a LOMO SPh-56 spectrophotometer. For these measurements, the cells were suspended in $50 \%$ glycerol. In addition, pigments were extracted with acetone/methanol $(1: 1$, $\mathrm{v} / \mathrm{v})$ and the absorption spectra of these extracts were recorded. For estimation of the pigment content, cells were harvested at approximately early stationary growth phase by centrifugation. Carotenoids were analysed by HPLC as described previously (Sidorova et al., 1998). Satisfactory separation of the pigments was achieved using a Spherisorb ODS2 column $(250 \times 4.6 \mathrm{~mm}, 5 \mu \mathrm{m}$; Waters $)$. The solvent flow rate was $1.0 \mathrm{ml} \mathrm{min}{ }^{-1}$. The column was equilibrated with a mixture composed of $77 \%$ acetonitrile/water $(9: 1$, $\mathrm{v} / \mathrm{v}$ ) and $23 \%$ ethyl acetate for $5 \mathrm{~min}$. The mixture was then linearly substituted by ethyl acetate. The total separation time varied from 25 to 30 min depending on the carotenoid composition. Pigment fractions were collected automatically and their absorption spectra were recorded on a Shimadzu UV-160 spectrophotometer (Toropygina et al., 2003). Quantitative estimations of the individual carotenoids were made using the absorbance coefficients given by Davies (1976) and Heinemeyer \& Schmidt (1983). For fatty acid and respiratory quinone analyses, cells of strains $\mathrm{RS}^{\mathrm{T}}$ and Rbl. acidophilus ATCC $25092^{\mathrm{T}}$ were grown on succinate mineral medium and harvested in the late exponential 

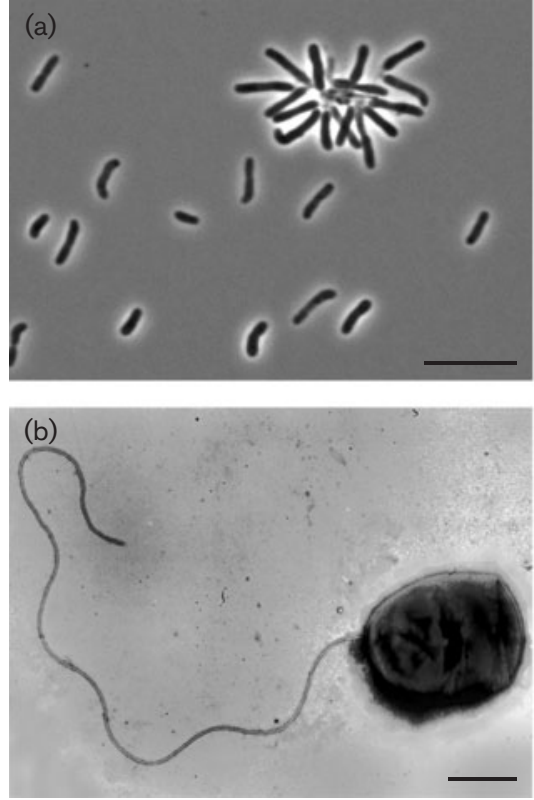

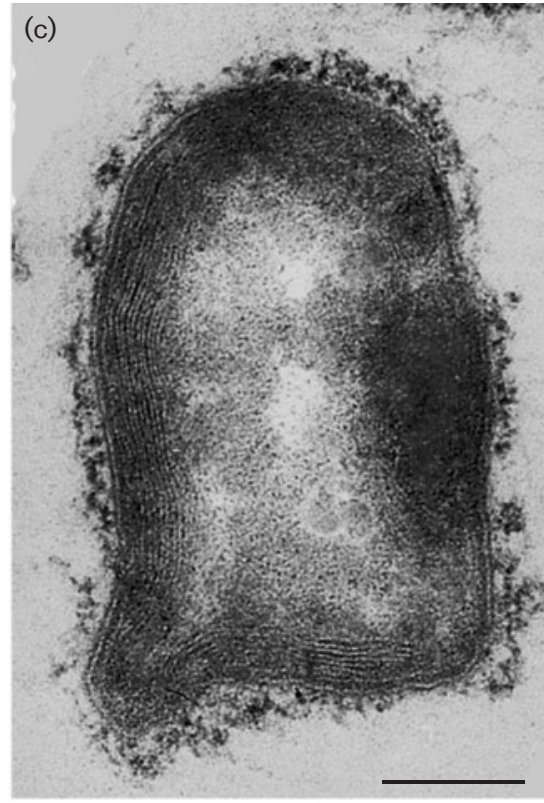

Fig. 1. (a) Phase-contrast micrograph of cells of strain $\mathrm{RS}^{\top}$ grown anaerobically in the light for 2 weeks. (b) Negatively stained young cell of strain $\mathrm{RS}^{\top}$ showing a single polar flagellum. (c) Electron micrograph of an ultrathin section showing lamellar intracytoplasmic membranes. Bars: $10 \mu \mathrm{m}$ (a) and $0.5 \mu \mathrm{m}(\mathrm{b}, \mathrm{c})$. growth phase. Analyses were performed by the Identification Service of the DSMZ. Genomic DNA from strain $\mathrm{RS}^{\mathrm{T}}$ was extracted by using the method of Marmur (1961). The DNA $G+C$ content was determined by means of thermal denaturation using a Unicam SP1800 spectrophotometer (at a heating rate of $0.5{ }^{\circ} \mathrm{C} \mathrm{min}^{-1}$ ) and calculated according to Owen et al. (1969). DNA-DNA hybridization of strain $\mathrm{RS}^{\mathrm{T}}$ and $\mathrm{Rbl}$. acidophilus ATCC $25092^{\mathrm{T}}$ was performed as described by De Ley et al. (1970). PCR-mediated amplification of the 16S rRNA gene from position 28 to 1491 (numbering according to the International Union of Biochemistry nomenclature for Escherichia coli 16S rRNA) was performed using primers Eub9f and Eub1492r and the reaction conditions described by Weisburg et al. (1991). The $16 \mathrm{~S}$ rRNA gene amplicons were purified using QIAquick spin columns (Qiagen) and sequenced on an ABI Prism 377 DNA sequencer using BigDye terminator chemistry, as specified by the manufacturer (PE Applied Biosystems). Phylogenetic analysis was carried out using the ARB program package (Ludwig et al., 2004).

Photosynthetically grown liquid cultures of strain $\mathrm{RS}^{\mathrm{T}}$ were purplish red in colour. Cells of this isolate were Gramnegative, large rods, $0 \cdot 8-1 \cdot 0 \mu \mathrm{m}$ in width and $2 \cdot 0-6 \cdot 0 \mu \mathrm{m}$ in length (Fig. 1a, b). They showed polar growth and they reproduced by budding. No tube or filament was formed between mother and daughter cells. Young cells were motile by means of a single polar flagellum, while in older cultures cells were non-motile and had a tendency to form rosettelike clusters. Electron microscopy of ultrathin sections revealed the presence of internal photosynthetic membranes appearing as lamellae underlying, and parallel to, the cytoplasmic membrane (Fig. 1c).

The photosynthetic pigments of strain RS $^{\mathrm{T}}$ were bacteriochlorophyll $a$ and carotenoids. The absorption spectrum of living cells showed maxima at 377, 463, 492, 527, 592, 806 and $867 \mathrm{~nm}$. The latter two peaks and the peak at $377 \mathrm{~nm}$ are characteristic of bacteriochlorophyll $a$ (see Supplementary Fig. S1 in IJSEM Online). The main absorption maxima detected in acetone/methanol extracts were at 803 and $863 \mathrm{~nm}$ (data not shown). Carotenoid analysis performed using HPLC identified rhodopin and rhodopinal as the major carotenoids $(57 \cdot 7 \%$ of total carotenoid content) of strain $\mathrm{RS}^{\mathrm{T}}$ (Table 1). Lycopene was the next greatest component $(12 \cdot 9 \%)$, followed by rhodopinol $(10 \cdot 9 \%)$, lycopenal $(6 \cdot 4 \%)$, rhodopinal glucoside $(5 \cdot 6 \%)$ and lycopenal glucoside $(5 \cdot 1 \%)$. A high content of carotenoid glucosides (38-40\%) was shown to be characteristic of Rbl. acidophilus (Schmidt, 1971; Heinemeyer \& Schmidt, 1983). However, in contrast to Rbl. acidophilus ATCC $25092^{\mathrm{T}}$, our isolate did not contain spirilloxanthin.

Table 1. Carotenoid compositions of acidophilic phototrophic isolate $\mathrm{RS}^{\top}$ and Rbl. acidophilus ATCC $25092^{\top}$

Values are percentages of total carotenoids; ND, not determined. Data for Rbl. acidophilus ATCC $25092^{\mathrm{T}}$ were taken from Heinemeyer \& Schmidt (1983).

\begin{tabular}{|lcc|}
\hline Carotenoid & Strain $\mathbf{R S}^{\mathbf{T}}$ & $\begin{array}{c}\text { Rbl. } \text { acidophilus } \\
\text { ATCC } \mathbf{2 5 0 9 2}^{\mathbf{T}}\end{array}$ \\
\hline Rhodopin & $28 \cdot 7$ & $25 \cdot 0$ \\
Rhodopinol & $10 \cdot 9$ & $0 \cdot 5$ \\
Rhodopinal & $29 \cdot 0$ & $5 \cdot 0$ \\
Rhodopinal glucoside & $5 \cdot 6$ & $38 \cdot 0$ \\
Lycopene & $12 \cdot 9$ & $5 \cdot 0$ \\
Lycopenal & $6 \cdot 4$ & $1 \cdot 0$ \\
Lycopenal glucoside & $5 \cdot 1$ & $\mathrm{ND}$ \\
Spirilloxanthin & 0 & $5 \cdot 0$ \\
\end{tabular}


Table 2. Cellular fatty acid composition of strain $\mathrm{RS}^{\top}$ and Rbl. acidophilus ATCC $25092^{\top}$

Values are percentages of total fatty acids; ND, not detected.

\begin{tabular}{|lcc|}
\hline Fatty acid & Strain $\mathbf{R S}^{\mathbf{T}}$ & $\begin{array}{c}\text { Rbl. } \text { acidophilus } \\
\text { ATCC } \mathbf{2 5 0 9 2}^{\mathbf{T}}\end{array}$ \\
\hline $14: 0$ & $0 \cdot 35$ & $0 \cdot 45$ \\
$15: 0$ & $0 \cdot 60$ & $\mathrm{ND}$ \\
$16: 1 \omega 7 c$ & $45 \cdot 40$ & $46 \cdot 78$ \\
$16: 1 \omega 5 c$ & $0 \cdot 31$ & $0 \cdot 17$ \\
$16: 0$ & $8 \cdot 68$ & $11 \cdot 36$ \\
$16: 03-\mathrm{OH}$ & $0 \cdot 79$ & $3 \cdot 08$ \\
$17: 0$ & $0 \cdot 23$ & $\mathrm{ND}$ \\
iso-17:0 3-OH & $0 \cdot 15$ & $0 \cdot 45$ \\
$18: 1 \omega 7 c$ & $42 \cdot 16$ & $35 \cdot 02$ \\
$18: 0$ & $0 \cdot 87$ & $0 \cdot 63$ \\
$20: 1 \omega 7 c$ & $0 \cdot 19$ & $0 \cdot 16$ \\
$20: 0$ & $0 \cdot 35$ & $0 \cdot 22$ \\
\hline
\end{tabular}

Strain $\mathrm{RS}^{\mathrm{T}}$ grew under anaerobic or microaerobic conditions in the light. No growth occurred under aerobic conditions in the dark. The following organic compounds served as carbon sources: formate, acetate, propionate, butyrate, pyruvate, valerate, malate, succinate, glycerol, methanol and ethanol. Best growth $\left(\mathrm{OD}_{600}\right.$ up to $\left.0 \cdot 7-0 \cdot 9\right)$ was observed on butyrate and propionate. Methanol was utilized over a concentration range of $0 \cdot 01-1 \%(\mathrm{v} / \mathrm{v})$, with the optimum between $0 \cdot 05$ and $0 \cdot 1 \%$. Slow growth was also detected on caproate, lactate and malonate. No growth occurred on glucose, fructose, citrate, benzoate, tartrate, mannitol, glutamate or arginine. Growth factors were not required, but the presence of yeast extract slightly increased the growth rate. Sulfate was assimilated. Good growth was observed on nitrogen-free medium. Thus, the nitrogen sources were ammonia and dinitrogen; nitrate was not utilized. Strain $\mathrm{RS}^{\mathrm{T}}$ was capable of photolithoautotrophic growth with molecular hydrogen and carbon dioxide. Hydrogen sulfide and thiosulfate were not utilized.

The isolate grew in the $\mathrm{pH}$ range $4 \cdot 8-7 \cdot 0$, with a $\mathrm{pH}$ optimum of $5 \cdot 2-5 \cdot 5$ (Supplementary Fig. S2). The temperature optimum for growth was $25-30^{\circ} \mathrm{C}$. Growth inhibition of $50 \%$ was observed in the presence of $1 \%(\mathrm{w} / \mathrm{v}) \mathrm{NaCl}$ in the medium, whereas $2 \% \mathrm{NaCl}$ inhibited growth completely.

The cellular fatty acid composition of strain $\mathrm{RS}^{\mathrm{T}}$ is shown in Table 2. Similarly to Rbl. acidophilus, the major components of the phospholipid fatty acid profile of strain $\mathrm{RS}^{\mathrm{T}}$ were straight-chain, monounsaturated 9-cis-hexadecenoic acid $(16: 1 \omega 7 c)$ and 11-cis-octadecenoic acid $(18: 1 \omega 7 c)$, which comprised 45.4 and $42 \cdot 2 \%$, respectively, of the total phospholipid fatty acid content. However, in comparison with that of Rbl. acidophilus ATCC $25092^{\mathrm{T}}$, the phospholipid fatty acid profile of the novel isolate contained a smaller percentage of 16:0 fatty acids and contained minor amounts $(<1 \%)$ of some other saturated fatty acids, such as $15: 0$ and $17: 0$. Cells of strain $\mathrm{RS}^{\mathrm{T}}$ contained ubiquinones Q-10 and Q-9, which comprised 92 and 8\%, respectively, of the total quinone content. In contrast to Rbl. acidophilus, strain $\mathrm{RS}^{\mathrm{T}}$ did not contain any menaquinones or rhodoquinones (Table 3).

Comparative sequence analysis of the 16S rRNA gene revealed that strain $\mathrm{RS}^{\mathrm{T}}$ belongs to the Alphaproteobacteria (Fig. 2). This novel phototrophic isolate is most closely related to the acidophilic phototrophic non-sulfur bacterium Rbl. acidophilus ATCC $25092^{\mathrm{T}}$ (97.3\% sequence similarity). Other closely related micro-organisms, exhibiting

Table 3. Major characteristics that differentiate Rhodoblastus sphagnicola sp. nov. and Rbl. acidophilus

Data for Rbl. acidophilus are from Pfennig (1969), Imhoff \& Trüper (1992) and Imhoff (2001b). + , Positive; -, negative; w, weakly positive.

\begin{tabular}{|lcc|}
\hline Characteristic & Rbl. sphagnicola $\mathbf{R S}^{\mathbf{T}}$ & Rbl. acidophilus \\
\hline Colour of culture & Purplish red & Red to orange-red \\
Cell diameter $(\mu \mathrm{m})$ & $0 \cdot 8-1 \cdot 0$ & $1 \cdot 0-1 \cdot 3$ \\
pH optimum & $5 \cdot 2-5 \cdot 5$ & $5 \cdot 5-6 \cdot 0$ \\
DNA G+ C content $(\mathrm{mol} \%)$ & $62 \cdot 6$ & $65 \cdot 3^{*}(62 \cdot 2-66 \cdot 8)$ \\
Aerobic growth in the dark & - & + \\
Spirilloxanthin present in carotenoids & - & + \\
Major quinones $\dagger$ & $\mathrm{Q}-10, \mathrm{Q}-9$ & $\mathrm{Q}-10, \mathrm{MK}-10, \mathrm{RQ}-10$ \\
Citrate photoassimilation & - & - \\
Glycerol photoassimilation & + & Poor \\
Phototrophic growth on butyrate & Good & \\
\hline
\end{tabular}

${ }^{*}$ Value for the type strain, Rbl. acidophilus ATCC $25092^{\mathrm{T}}$. The range of values reported for other strains is given in parentheses.

$\dagger \mathrm{MK}$, Menaquinone; Q, ubiquinone; RQ, rhodoquinone. 
overall $16 \mathrm{~S}$ rRNA gene sequence similarity of $94 \%$ with respect to strain $\mathrm{RS}^{\mathrm{T}}$, are acidophilic methanotrophic bacteria of the genera Methylocella and Methylocapsa and acidophilic heterotrophic bacteria of the genus Beijerinckia. Interestingly, most known representatives of the genera Methylocella and Methylocapsa were also isolated from acidic Sphagnum peatlands (Dedysh et al., 2000, 2002, 2004). Together, these phototrophic, heterotrophic and methanotrophic bacteria of the genera Rhodoblastus, Beijerinckia, Methylocella and Methylocapsa form a monophyletic cluster, which is supported by a bootstrap value of $97 \%$ (Fig. 2). All members of this phylogenetic cluster are moderately acidophilic organisms that inhabit acidic, boggy waters and soils and have a $\mathrm{pH}$ optimum for growth of about $5 \cdot 5$. A metabolic trait common to all organisms of this phylogenetic group, including those in the genus Beijerinckia (Dedysh et al., 2005), is the capacity for methylotrophic growth.

The DNA G $+\mathrm{C}$ content of strain $\mathrm{RS}^{\mathrm{T}}$ was found to be $62.6 \mathrm{~mol} \%$. The corresponding value for the type strain (ATCC $25092^{\mathrm{T}}$ ) of $\mathrm{Rbl}$. acidophilus, reported previously (Mandel et al., 1971) and also determined in our experiments, is $65 \cdot 3 \mathrm{~mol} \%$, while the DNA G+C contents of other strains of this species range from $62 \cdot 6$ to $66 \cdot 8 \mathrm{~mol} \%$ (Pfennig, 1969; Imhoff, 2001b). The DNA-DNA hybridization value for strain $\mathrm{RS}^{\mathrm{T}}$ and $\mathrm{Rbl}$. acidophilus ATCC $25092^{\mathrm{T}}$ was only $22 \%$. This low level of genomic DNA relatedness suggests a differentiation of the two strains at the species level, which is also supported by the results of some physiological tests. Strain $\mathrm{RS}^{\mathrm{T}}$ should therefore be assigned to a novel species of the genus Rhodoblastus, for which the name
Rhodoblastus sphagnicola is proposed. The characteristics that differentiate this novel species from $R b l$. acidophilus are summarized in Table 3.

\section{Description of Rhodoblastus sphagnicola sp. nov.}

Rhodoblastus sphagnicola (sphag.ni' co.la. N.L. n. Sphagnum generic name of sphagnum moss; L. suff. -cola from L. n. incola inhabitant, dweller; N.L. n. sphagnicola inhabitant of Sphagnum).

Cells are rod-shaped, straight or slightly curved, $0 \cdot 8-1 \cdot 0 \mu \mathrm{m}$ wide and $2 \cdot 0-6 \cdot 0 \mu \mathrm{m}$ long, motile by polar flagella in young cultures and have a tendency to form rosette-like clusters in older cultures. Cells reproduce by budding. No tube or filament is formed between mother and daughter cells. Cells contain lamellar intracytoplasmic photosynthetic membranes underlying, and parallel to, the cytoplasmic membrane. The colour of anaerobic liquid cultures is purplish red. Absorption spectra of living cells show maxima at $377,463,492,527,592,806$ and $867 \mathrm{~nm}$. The photosynthetic pigments are bacteriochlorophyll $a$ and carotenoids. Rhodopin and rhodopinal are major carotenoids, followed by lycopene, rhodopinol, lycopenal, rhodopinal glucoside and lycopenal glucoside. Spirilloxanthin is absent from the carotenoid composition. Preferred mode of growth is photoheterotrophic under anoxic conditions in the light with formate, acetate, butyrate, pyruvate, lactate, propionate, malate, malonate, succinate, glycerol, methanol, ethanol, caproate, lactate and malonate. Best growth occurs on

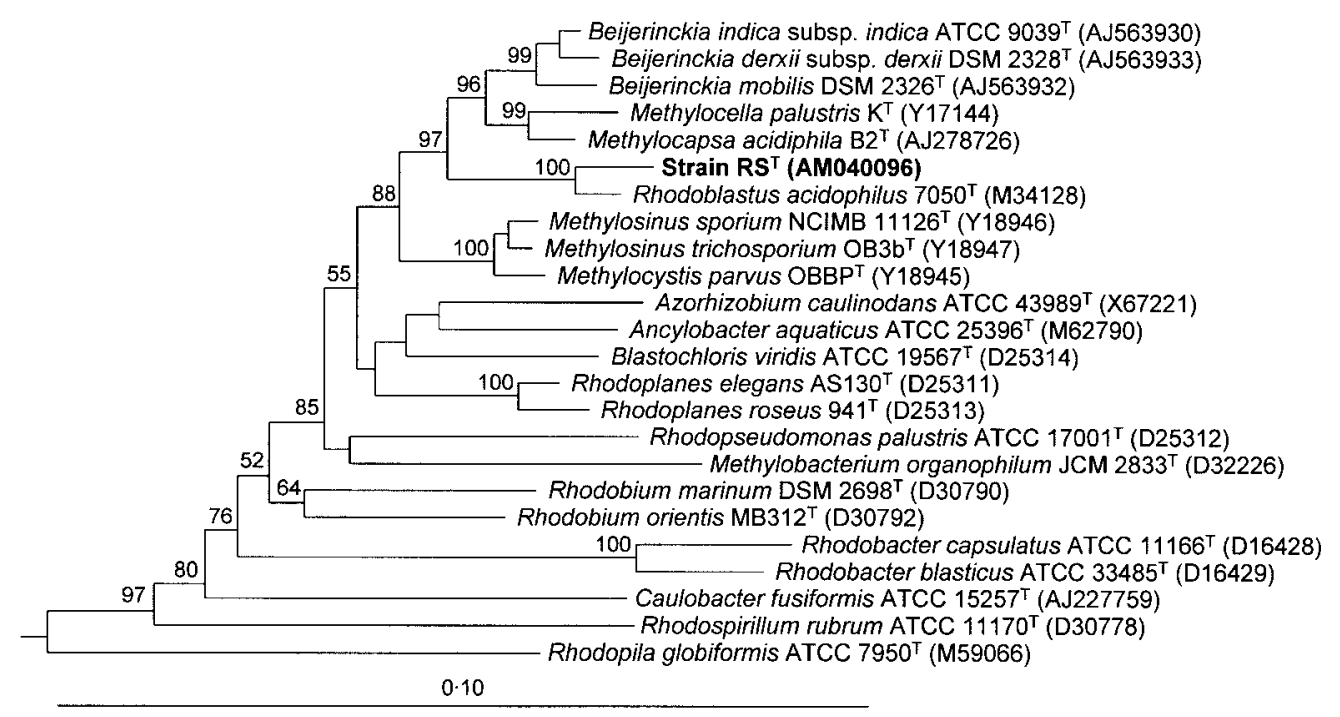

Fig. 2. Neighbour-joining tree, based on $16 \mathrm{~S}$ rRNA gene sequences, showing the phylogenetic position of strain $\mathrm{RS}^{\top}$ in relation to Rbl. acidophilus ATCC $25092^{\top}$, acidophilic methanotrophs of the genera Methylocella and Methylocapsa, acidophilic heterotrophic bacteria of the genus Beijerinckia and some other representative members of the Alphaproteobacteria. The root was determined by using the 16S rRNA gene sequence of Pseudomonas stutzeri A1501 (GenBank accession no. AF143245) as the outgroup (not shown). Bootstrap percentages (from 1000 data resamplings) greater than $50 \%$ are shown. Bar, $0 \cdot 1$ substitutions per nucleotide position. 
butyrate and propionate. Methanol is utilized at a wide range of concentrations from 0.01 to $1 \%(\mathrm{v} / \mathrm{v})$. No growth occurs with benzoate, glucose, fructose, tartrate, citrate or glutamate. Nitrogen sources are $\mathrm{N}_{2}$ and ammonia. Photoautotrophic growth is possible with hydrogen as electron donor; sulfide and thiosulfate cannot be used. Growth factors are not required, though yeast extract increases the growth rate. No aerobic growth occurs in the dark. The major phospholipid fatty acids are $16: 1 \omega 7 c$ and $18: 1 \omega 7 c$. Contains ubiquinones Q-10 and Q-9. Mesophilic, moderately acidophilic, with optimum growth at $25-30{ }^{\circ} \mathrm{C}$ and $\mathrm{pH} 5 \cdot 2-5 \cdot 5 . \mathrm{NaCl}$ inhibits growth at concentrations above $1 \%(\mathrm{w} / \mathrm{v})$. The DNA G $+\mathrm{C}$ content is $62 \cdot 6 \mathrm{~mol} \%$.

The type strain, $\mathrm{RS}^{\mathrm{T}}\left(=\mathrm{DSM} 16996^{\mathrm{T}}=\mathrm{VKM} \mathrm{B}-2361^{\mathrm{T}}\right)$, was isolated from an acidic Sphagnum peat bog (Sosvyatskoe), Tver Region, Russia.

\section{Acknowledgements}

This research was supported, in part, by the Russian Fund for Basic Research (grant no. 04-04-04000), the Program 'Molecular and Cell Biology' of the Russian Academy of Sciences, the Russian Science Support Foundation and the Deutsche Forschungsgemeinschaft (436 RUS 113/543/0-3). We thank A. M. Lysenko and N. A. Kostrikina (S. N. Winogradsky Institute of Microbiology, Russian Academy of Sciences) for DNA-DNA hybridization analyses and assistance with electron microscopy and Z. K. Mahneva and A. A. Moskalenko (G. K. Skryabin Institute of Biochemistry and Physiology of Microorganisms, Russian Academy of Sciences) for carotenoid analyses.

\section{References}

Burke, M. E., Corham, E. \& Pratt, D. C. (1974). Distribution of purple photosynthetic bacteria in wetland and woodland habitats of central and northern Minnesota. J Bacteriol 117, 826-833.

Davies, B. H. (1976). Carotenoids. In Chemistry and Biochemistry of Plant Pigments, 2nd edn, pp. 38-160. Edited by T. W. Goodwin. London: Academic Press.

Dedysh, S. N., Liesack, W., Khmelenina, V. N., Suzina, N. E., Trotsenko, Y. A., Semrau, J. D., Bares, A. M., Panikov, N. S. \& Tiedje, J. M. (2000). Methylocella palustris gen. nov., sp. nov., a new methaneoxidizing acidophilic bacterium from peat bogs, representing a novel subtype of serine-pathway methanotrophs. Int J Syst Evol Microbiol 50, 955-969.

Dedysh, S. N., Khmelenina, V. N., Suzina, N. E., Trotsenko, Y. A., Semrau, J. D., Liesack, W. \& Tiedje, J. M. (2002). Methylocapsa acidiphila gen. nov., sp. nov., a novel methane-oxidizing and dinitrogen-fixing acidophilic bacterium from Sphagnum bog. Int J Syst Evol Microbiol 52, 251-261.

Dedysh, S. N., Berestovskaya, Y. Y., Vasylieva, L. V., Belova, S. E., Khmelenina, V. N., Suzina, N. E., Trotsenko, Y. A., Liesack, W. \& Zavarzin, G. A. (2004). Methylocella tundrae sp. nov., a novel methanotrophic bacterium from acidic tundra peatlands. Int J Syst Evol Microbiol 54, 151-156.

Dedysh, S. N., Smirnova, K. V., Chmelenina, V. N., Suzina, N. E., Liesack, W. \& Trotsenko, Y. A. (2005). Methylotrophic autotrophy in Beijerinckia mobilis. J Bacteriol 187, 3884-3888.

De Ley, J., Cattoir, H. \& Reynaerts, A. (1970). The quantitative measurement of DNA hybridization from renaturation rates. Eur J Biochem 12, 133-142.
Heinemeyer, E.-A. \& Schmidt, K. (1983). Changes in carotenoid biosynthesis caused by variations of growth condition in cultures of Rhodopseudomonas acidophila strain 7050. Arch Mikrobiol 134, 217-221.

Imhoff, J. F. (2001a). The phototrophic alpha-Proteobacteria. In The Prokaryotes: an Evolving Electronic Resource for the Microbiological Community, 3rd edn, release 3.6, 22 June 2001. Edited by M. Dworkin \& others. New York: Springer. http://141.150.157.117:8080/ prokPUB/index.htm

Imhoff, J. F. (2001b). Transfer of Rhodopseudomonas acidophila to the new genus Rhodoblastus as Rhodoblastus acidophilus gen. nov., comb. nov. Int J Syst Evol Microbiol 51, 1863-1866.

Imhoff, J. F. \& Trüper, H. G. (1992). The genus Rhodospirillum and related genera. In The Prokaryotes, 2nd edn, pp. 2141-2155. Edited by A. Balows, H. G. Trüper, M. Dworkin, W. Harder \& K. H. Schleifer. New York: Springer.

Kawasaki, H., Hoshinoi, Y. \& Yamasato, K. (1993). Phylogenetic diversity of phototrophic purple non-sulfur bacteria in the Proteobacteria alpha-group. FEMS Microbiol Lett 112, 61-66.

Ludwig, W. O., Strunk, R., Westram, L. \& 29 other authors (2004). ARB: a software environment for sequence data. Nucleic Acids Res 32, 1363-1371.

Mandel, M., Leadbetter, E. R., Pfennig, N. \& Trüper, H. G. (1971). Deoxyribonucleic acid base compositions of phototrophic bacteria. Int J Syst Bacteriol 21, 222-230.

Marmur, J. (1961). A procedure for the isolation of DNA from microorganisms. J Mol Biol 3, 208-218.

Owen, R. J., Lapage, S. P. \& Hill, L. R. (1969). Determination of base composition from melting profiles in dilute buffers. Biopolymers $\mathbf{7}$, 503-516.

Pfennig, N. (1969). Rhodopseudomonas acidophila, sp. n., a new species of the budding purple nonsulfur bacteria. J Bacteriol 99, 597-602.

Pfennig, N. \& Lippert, K. D. (1966). Über das Vitamin $B_{12}$-Bedürfnis phototropher Schwefelbakterien. Arch Mikrobiol 55, 258-266 (in German).

Pratt, D. C. \& Gorham, E. (1970). Occurrence of Athiorhodaceae in woodland, swamp, and pond soils. Ecology 51, 346-349.

Schmidt, K. (1971). Carotenoids of purple nonsulfur bacteria. Arch Mikrobiol 77, 231-238.

Sidorova, T. N., Makhneva, Z. K., Puchkova, N. N., Gorlenko, V. M. \& Moskalenko, A. A. (1998). Characteristics of photosynthetic apparatus of Thiocapsa strain BM3 containing okenone as the main carotenoid. Microbiology (English translation of Mikrobiologiia) 67, 199-206.

Stackebrandt, E., Murray, R. G. E. \& Trüper, H. G. (1988). Proteobacteria classis nov., a name for the phylogenetic taxon that includes the "purple bacteria and their relatives". Int J Syst Bacteriol 38, 321-325.

Toropygina, O. A., Makhneva, Z. K. \& Moskalenko, A. A. (2003). Reconstitution of carotenoids into the light-harvesting complex B800-850 of Chromatium minutissimum. Biochemistry (English translation of Biokhimiia) 68, 901-911.

Weisburg, W. G., Barns, S. M., Pelletier, D. A. \& Lane, D. J. (1991). 16 S ribosomal DNA amplification for phylogenetic study. J Bacteriol 173, 697-703.

Woese, C. R., Stackebrandt, E., Weisburg, W. G. \& 8 other authors (1984). The phylogeny of purple bacteria: the alpha subdivision. Syst Appl Microbiol 5, 315-326.

Wolin, E. A., Wolin, M. G. \& Wolfe, R. S. (1963). Formation of methane by bacterial extracts. J Biol Chem 238, 2882-2886. 